\title{
Pengaruh Gaya Hidup, Demografi Dan Kualitas Produk Terhadap Keputusan Pembelian Konsumen Alfamart Sukaseuri Cikampek
}

\author{
Suhardi \\ Universitas Bina Sarana Informatika Jakarta \\ e-mail: suhardi.sdw@bsi.ac.id
}

\begin{abstract}
Lifestyle change in the demographic structure of society, especially in city of Karawang area who believe that shopping at modern retail outlets add to the prestigue of its own in the social life makes competition in the provision of retail entrepreneurs staples and daily necessities has increased mainly about improved quality of goods and services led to the the level of consumer purchasing decisions.The Purpose of Research are analizing the Effect of life style, demography and product quality toward customer buying desicion partially and simultaneously.This Research is done at alfamart outlet Mitra Usaha CV. Family which located at Jl. Ir. H. Juanda Cikampek Karawang. This Research used 80 respondents determined by purposive sampling technic due to the unlimited population.This reseach uses multiple regression analysis by using three independent variables and one dependent variable.The result of research shows that life style,demography dan product quality proved positive and significant effect to customer buying desicion partially and simultaneously.Therefore, life style, demography and product quality are important factors to increase buying desecion.
\end{abstract}

Keyword: Life Style, Demography, Product Quality and Buying Desicion

\section{PENDAHULUAN}

Pergeseran budaya masyarakat dari masyarakat tradisonal menuju gaya hidup modern menjadikan perubahan gaya hidup dalam setiap aspek kehidupan masyarakat, hal tersebut tidak hanya terjadi pasa masyarakat perkotaan melainkan merambah ke masyarakat daerah, termasuk masyarakat kabupaten karawang jawa barat yang mencapat kepadatan penduduk sebesar 2.288.181 jiwa (BPS Karawang, 2019) yang ditandai oleh beberapa perubahan pola hidup masyarakat daerah tersebut, salah sarunya dalam memilih gerai tempat berbelanja yang dinilai bisa memenuhi kebutuhan mereka sehari-hari.

Sebagian besar masyarakat daerah menganggap berbelanja di gerai retail masih dinilai memiliki nilai sosial atau gengsi tersendiri, yang mampu mengangkat kesan akan status dirinya. Kemudian sering pula ditemui bahwa gerai retail semacam ini tidak hanya dimanfaatkan untuk tempat berbelanja semata, melainkan juga menjadi tempat santai-santai di selasar gerai, karena beberapa gerai retail disediakan juga tempat santai lengkap dengan fasilitas tambahan seperti tempat mengisi batray segala jenis merk handphone gratis yang disediakan untuk para pelanggan gerai selepas belanja atau sambil menuggu kedatangan bis atau jemputan. Peluang semacam ini telah dimanfaatkan oleh pelaku bisnis gerai ritel untuk menarik konsumen lebih banyak lagi dengan cara menyediakan model pelayanan jasa yang benar-benar dibutuhkan oleh masyarakat sekitarnya dan mendukung perubahan gaya hidup konsumen, dengan demikian masyarakat tidak segan untuk melakukan pembelian di gerai tersebut.

Perkembangan gerai retail di Indonesia sangat pesat dan mengiurkan untuk pebisnis yang tertaris di bidang ini, bukan hanya yang berasal dari Indonesia, namun juga banyak perusahaan luar negeri dan menjadikan Indonesia sebagai kawasan invansi bisnis mereka. Dandan, Lawson, Alfamidi dan Alfamart yang masih bernaung dalam satu gruop bisnis juga berkembang di Indonesia. namun yang paling berkembang di Indonesia adalah Alfamart.

PT Sumber Alfaria Trijaya Tbk terus melakukan ekspansi bisnisnya bukan hanya di Indonesia namun juga merampah ke luar negeri dan menjadikan Filipina sebagai pusat ekspansinya. Pada 2017, perusahaan ritel asal Indonesia tersebut menargetkan akan membuka 400 gerai Alfamat di Manila.

Berdasarkan data yang didapat dari katadata.com emiten yang memiliki kode perdagangan ALFA tersebut pada September 2017 memiliki 14.923 gerai bertambah 1.208 dari 13.715 unit pada Desember 2016. Adapun jumlah Alfamart pada September 2017 berjumlah mencapai 13.376 gerai bertambah 1.040 dari posisi akhir 2016 sebanyak 12.336 gerai.Adapun gerai Alfamidi pada September 2017 bertambah 175 menjadi 1.405 gerai dari posisi Desember 2016 sebanyak 1.230 gerai. Kemudian gerai Lawson bertambah 2 menjadi 37 gerai. Sedangkan jumlah gerai Dan Dan berkurang 9 menjadi 105 gerai. Berikut perkembangan gerai alfa group selama bulan desember 2016 sampai 
sepetember 2017.

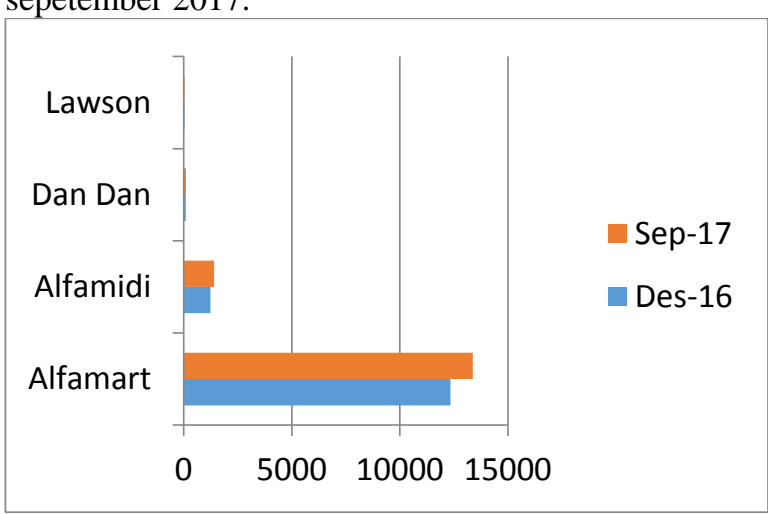

Gambar 1 Pertumbuhan Gerai Alfa Group

Sumber : (katadata.co.id.)

Jika dilihat dari jumlah penduduk Karawang pada tahun 2018 yaitu sebanyak 2.288.181 jiwa, dengan tingkat pertumbuhan rata-rata $3,8 \%$ per tahun, sedangkan pertumbuhan jumlah Gerai retail lebih cepat dibandingkan dengan pertumbuhan penduduk. Di sisi lain, jumlah konsumen di industri retail di Karawang dalam satu tahun terakhir, cenderung meningkat tiap tahun dengan pertumbuhan rata-rata $7,7 \%$. Artinya bahwa pertumbuhan kapasitas jasa gerai retail belum mampu mengimbangi lonjakan konsumen. Kondisi tersebut menunjukkan bahwa bisnis semacam ini memiliki kecendrungan pasar yang menguntungkan. Dengan fakta tersebut menunjukkan gaya hidup masyarakat daerah mengalami perubahan gaya hidup yang cepat.

Perkembangan gerai dari tahun ke tahun mengalami lojakan yang luar biasa (Dewi, 2015). Lonjakan konsumen ritel berkorelasi dengan perubahan pola konsumsi dan sikap penduduk sekitarnya. Namun bukan tanpa masalah yang berarti, Berbagai macam hambatan pasti akan ditemui oleh perusahaan untuk dapat menigkatkan penjualan pada setiap gerai untuk mendapat keuntungan yang terus meningkat. Banyak faktor yang dapat mempengaruhi menurunya daya beli masyarakat, antara lain, pelayanan, fasilitas, komunikasi, harga dan masih banyak yang lainnya. Semua faktor itu pasti berpengaruh dengan tingkatannya masing-masing.

Berdasarkan hasil wawancara dengan kepala gerai alfamart mitra usaha cv family, penjualan gerainya berjalan dengan normal. Tetapi tentunya sebagai seorang yang bergerak dibidang bisnis perjualan normal saja tidak cukup karena persaingan semakin ketat antara gerai ritel dari perusahaan lain. Perlu ada upaya penigkatan yang berujung pada penigkatan penjulan di gerainya.

Keputusan pembelian adalah pemilihan dari dua atau lebih alternatif pilihan keputusan pembelian, artinya bahwa seseorang dapat memuat keputusan, haruslah tersedia beberapa alternatif pilihan (Ghanimata \& Kamal,2012).Keputusan pembelian merupakansesuatu yang berhubungan erat dengan rencana konsumen terkait lokasi pembelian produk yang dibutuhkannya. Pemasar sebagai pihak yang menawarkan berbagai produk kepada konsumen harus dapat menganalisis faktor faktor yang mempengaruhi konsumen dalam pemilihan lokasi pembelian produk. Dimensi yang digunakan schiffman untuk mengukur keputusan pembelian antara lain adalah:

1. Cepat dalam memutuskan, yaitu keputusan pembelian yang melihat apakah konsumen cepat dalam memutuskan keputusan pembelian produk.

2. Pembelian sendiri, yaitu melihat apakah keputusan pembelian yang dilakukan oleh konsumen berdasarkan keingainan pribadinya.

3. Bertindak karena keunggulan produk, yaitu keputusan pembelian yang dilakukan karena melihat dari keunggulan produk tersebut.

4. Keyakinan atas pembelian, keputusan pembelian yang dilakukan konsumen secara yakin tanpa ada keraguan.

Gaya hidup didefinisikan sebagai pola dimana orang hidup dan menghabiskan waktu serta uang (Ardy, 2013). Sedangakan Menurut World Healt Organization (WHO) mendefinisikan gaya hidup sebagai "life style is a way of living based on identifiable patterns of behaviour which are determined by the inter play between an individual's personal characteristics, social interactions, and socialeconomic and environmental living condition." (Fuad, 2015). Dengan kata lain gaya hidup adalah cara hidup berdasarkan pola yang diidentifikasi dari perilaku yang ditentukan oleh interaksi antara karakteristik individu pribadi, interaksi sosial, dan kondisi hidup sosial ekonomi dan lingkungan. Dengan demikin Gaya hidup mempunyai dimensi-dimensi sebagai Interaksi antara karakteristik individu pribadi, Interaksi sosial dan Kondisi sosial.

Menurut Donald J. Bougue mendefinisikan demografi sebagai pengelompokan secara statistik mengenai jumlah,komposisi,distribusi pendudukdan perubahan-perubahannya sebagai akibat bekerjanya komponen-komponen pertumbuhan penduduk (Harmadi, 2008). Dengan kata lain demografi adalah uraian tentang penduduk, terutama tentang kelahiran, perkawinan, kematian, dan migrasi. Demografi meliputi studi ilmiah tentang jumlah, persebaran geografis, komposisi penduduk, serta bagaimana faktor-faktor ini berubah. Berikut adalah dimensi-dimensiyang bisa dipakai untuk mengukurnya: Bauran umur populasi, etnis, kelompok pendidikan, pola rumah tangga, pergeseran geografis dalam populasi.

Kualitas dapat diartikan kemampuan dari produk untuk menjalankan fungsinya yang mencakup daya tahan, kehandalan atau kemajuan, kekuatan, kemudahan dalam pengemasan dan reparasi produk 
dan ciri-ciri lainnya (Kodu \& Produk, 2012). Kualitas produk juga diartikan sebagai evaluasi secara keseluruhan dari pelanggan tentang keunggulan kinerja suatu barang atau jasa (Permana, 2013) . Lebih lanjut Mowen dan Minor menerangkan empat dimensi untuk mengukur kualitas dari sebuah produk. Dimensi- dimensi kualitas produk sebagai berikut:

1. Kinerja (performance), karakteristik operasi suatu produk yang paling mendasar dan utama.

2. Keandalan (Reliability), kemungkinan bahwa produk tersebut bisa tetap bermutu baik dalam janka waktu yang ditentukan

3. Daya tahan (Durability), berkaitan dengan berapa lama produk tersebut dapat digunakan.

4. Keamanan ( Safety), menyangkut keamanan saat produk itu dikonsumsi atau digunakan (Ghanimata \& Kamal, 2012)

Dari kajian teori diatas penelitian yang relevan penulis menduga sebagai berikut :

a. Adanya pengaruh antara gaya hidup terhadap keputusan pembelian.

b. Adanya pengaruh antara demografi terhadap keputusan pembelian.

c. Adanya pengaruh antara kualitas produk terhadap keputusan pembelian.

d. Adanya pengaruh antara gaya hidup, demografi dan kualitas produk terhadap keputusan pembelian

Dengan demikian maka pengembangan kerangka berfikir dan hipotesis dapat digambarkan sebagai berikut :

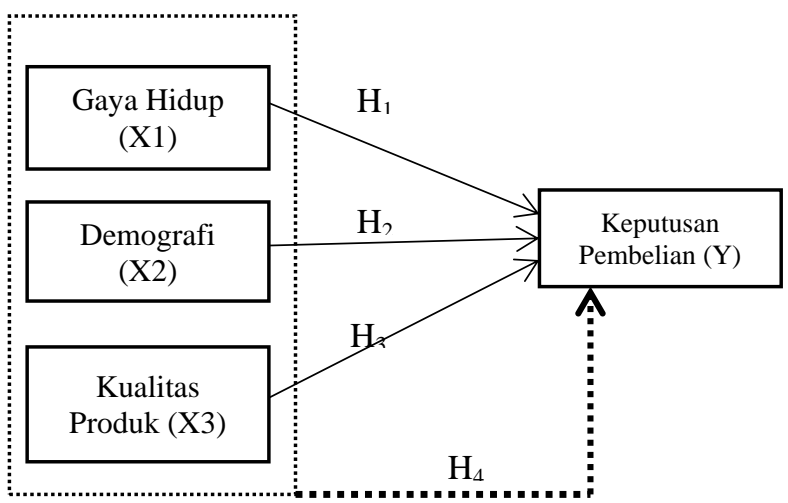

Gambar 2 Kerangka Berpikir Penelitian

Sumber: (H. Sugiyono, 2016)

\section{METODOLOGI PENELITIAN}

\section{A. Tempat Penelitian}

Tempat penelitian adalah Gerai Alfamart Sukaseuri Cikampek, ditempat ini peneliti mendapatkan banyak sumber data primer dan sekunder yang bisa peneliti gunakan dalam proses penelitian, didukung juga dengan dengan adanya fasilitas tempat duduk santai dan internet yang sangat membantu peneliti dalam mengakses data - data. Lokasi Penelitiannya pada Gerai Alfamart Sukaseuri Cikampek dengan alamat J1. Ir H Juanda no 23 Sukareuri Cikampek Karawang.

\section{B. Desain Penelitian}

Data statistik yang diolah ada 2 (dua) yaitu data kuantitatif dan data kualitatif. Adapun data kuantiatif adalah data yang berbentuk bilangan atau angka-angka misal data para guru. Sedangkan data kualitatif adalah data yang merupakan kategori sifat dengan ciri-ciri tertentu misal : sangat baik, baik, cukup baik, kurang baik, sangat kurang baik.

Tahapan dalam penelitian ini adalah :

a. Merancang penelitian

Dalam tahapan ini peneliti merumuskan bentuk penelitian yang akan dilakukan yaitu penelitian kuantitatif.

b. Menentukan populasi dan sampel

Dalam tahapan ini peneliti menentukan populasi dalam penelitian ini adalah pelanggan Gerai Alfamart Sukaseuri Cikampek dan sampel yang akan diambil sebanyak 80 orang.

c. Menentukan model penelitian

Dalam tahapan ini model penelitian apa yang akan di pakai yaitu model penelitian analisis regresi berganda.

d. Mendefinisikan variabel dan indikator penelitian

Dalam tahapan ini peneliti menentukan variabel-variabel yang akan digunakan dalam penelitian ini adalah GH (Gaya Hidup), D (Demografi), KP (Kualitas Produk) serta variabel tidak bebas (terikat) adalah KPP (Keputusan Pembelian Pelanggan). Kemudian menentukan indikator dari variabel bebas dan terikat yang akan digunakan dalam kuesioner.

e. Kuesioner

Dalam tahapan ini peneliti membuat kuesioner berdasarkan indikator yang sudah ditentukan sebelumnya. Kemudian disebarkan kepada responden untuk di isi sehingga mendapatkan informasi yang dibutuhkan. Responden dalam penelitian ini adalah pelanggan Gerai Alfamart Sukaseuri Cikampek.

f. Pengumpulan Data

Dalam tahapan ini adalah penyebaran serta pengumpulan kuesioner dari para responden yang terpilih.

g. Menganalisa data

Dari kuesioner yang telah disebarkan serta sudah di isi oleh responden, dikumpulkan kembali oleh peneliti untuk analisa data

h. Analisis Regresi Linear Berganda Dalam tahapan ini peneliti melakukan analisa data dengan menggunakan software SPSS 20

i. Menarik kesimpulan 
Dalam tahapan penelitian ini setelah dilakukan analisa data dengan SPSS 20 maka di tarik kesimpulan dari permasalahan yang diteliti.

\section{Populasi dan Sampel}

Populasi adalah wilayah generalisasi yang terdiri atas: obyek/subyek yang mempunyai kualitas dan karakteristik tertentu yang ditetapkan oleh peneliti untuk dipelajari dan kemudian ditarik kesimpulannya (Herawati, 2014) Populasi dalam penelitian ini adalah para konsumen gerai alfamart sukaseuri cikampek dengan jumlah populasi sebanyak 100 konsumen.

Sampel adalah bagian dari jumlah dan karakteristik yang dimiliki oleh populasi (Ediyanto \& Satyahadewi, 2013) Jumlah sampel yang diambil dalam melakukan penelitian di Gerai Alfamart Sukaseuri Cikampek adalah 80 orang atau pelanggan.

\section{HASIL PENELITIAN}

\section{A. Karakteristik Responden}

Berdasarkan hasil koesioner yang disebarkan kepada 80 orang responden yakni para pelanggan Gerai Alfamart Sukaseuri Cikampek, penulis memperoleh karekteristik responden yang terdiri dari jenis kelamin dan pendidikan. Diperoleh informasi bahwa sebagian besar dari responden atau pelanggan Gerai Alfamart Sukaseuri Cikampek adalah pria 46,25\% sedangkan sisanya perempuan $53,75 \%$.

Berdasarkan data terlihat bahwa responden Gerai Alfamart Sukaseuri Cikampek memiliki tingkat usia berbeda-beda, namun jika dilihata dari aspek pendidikan responden paling banyak didominasi oleh responden yang berpendidikan SLTA sebesar $42,5 \%$. Berikut karakteristik responden dalam bentuk tabel:

Tabel 1 Karakteristik Pelanggan Gerai Alfamart Sukaseuri Cikampek.

Klasifikasi Responden Jumlah Persentase

\begin{tabular}{clrr} 
& & \multicolumn{1}{c}{$\%$} \\
\hline \multirow{3}{*}{ Jender } & Pria & 37 & 46.25 \\
& Wanita & 43 & 53.75 \\
& Jumlah & 80 & 100 \\
& SLTA & 34 & 42.5 \\
& D3 & 27 & 33.75 \\
& S1 & 14 & 17.5 \\
& S2 & 5 & 6.25 \\
& Jumlah & $\mathbf{8 0}$ & $\mathbf{1 0 0}$ \\
\hline
\end{tabular}

Sumber: Data yang Diolah

\section{B. Uji Persyaratan Analisis}

Uji persyaratan Analisis data dilakukan dengan menggunakan korelasi antar variabel. Sebelum melakukan analisis data untuk mencari pengaruh antara variabel yang dipakai untuk penelitian, dilakukan uji prasyarat analisis yang meliputi uji analsisi statistik menggunakan aplikasi komputer SPSS 20, uji persyaratan analisis sebagai berikut :

\section{Uji Normalisasi Data}

Uji normalitas bertujuan untuk menguji apakah dalam model regresi, variabel pengganggu atau residual memiliki distribusi normal, bila asumsi ini dilanggar maka uji statistik menjadi tidak valid untuk jumlah sampel kecil. Model regresi yang baik adalah distribusi mendekati normal. Uji ini dilakukan dengan bantuan program for society science (SPSS) metode normal probability plot (NPP).(Ghozali, 2011)

Uji normalitas data pada penelitian ini menggunakan aplikasi komputer Statistical Package for the Social Sciences (SPSS) dengan modul uji normalitas Kolmogorov Smirnov. Uji Kolmogorov Smirnov adalah uji banding distribusi data dengan distribusi normal yang sudah baku. Distribusi normal baku adalah data yang telah ditranspormasikan kedalam bentuk z-score dan diasumsikan normal. Jadi dengan kata lain uji kolmogorov smirnov merupakan uji beda antara data yang diuji normalitasnya dengan data normal baku. Seperti pada uji beda lainnya, jika signifikansi di bawah 0.05 dinyatakan tidak normal dan sebalikknya jika signifikansi di atas 0.05 maka dinyatakan normal. Untuk mengetahui suatu instrumen dikatakan valid, yaitu dengan membandingkan nilai signifikansi masing-masing indikator dengan taraf signifikansi sebesar $\alpha=0,05$ (5\%). Jika signifikansi (1-tailed) kurang dari 0,05, maka butir pernyataan tersebut dinyatakan valid dan begitu pula sebaliknya.

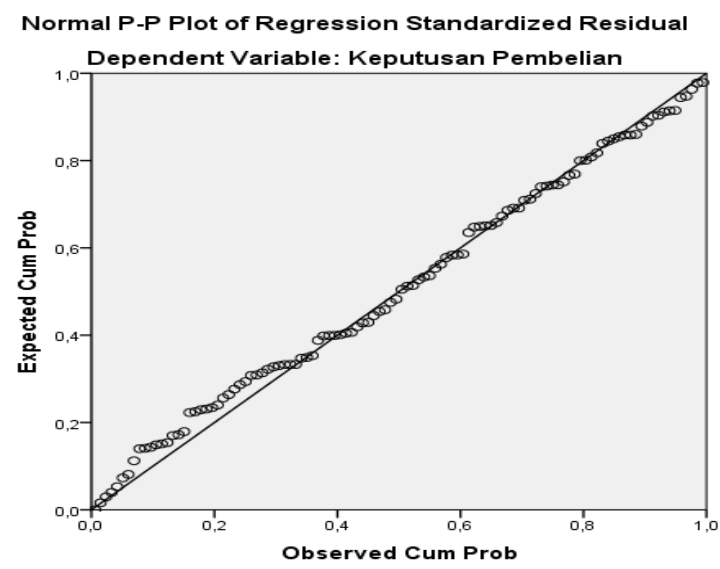

Gambar 3 Normal P-P Plot of Regretion Standardized Residual Keputusan Pembelian Sumber : Data SPSS yang diolah,2019

Dapat dilihat bahwa adanya titik-titik yang menyebar dan disekitar garis diagonal serta penyebarannya pun mengikuti arah garis diagonal. Hal tersebut membuktikan bahwa model regresinya telah memenuhi asumsi normalitas atau dengan kata 
lain data terdistribusi nornal. Selain ditunjukkan dengan gambar 3 Normal $P-P$ of Regresion Standardized Residual untuk keputusan pembelian, variabel independen Gaya Hidup, Demografi dan Kualitas Produk ditunjukkan dengan Histogram berikut:

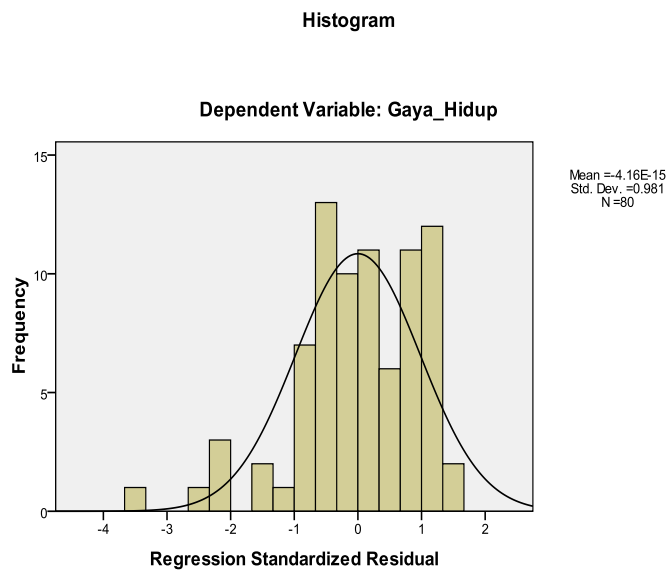

Gambar 4 Histogram Variabel Gaya Hidup (X1) Sumber : Data SPSS yang diolah 2019

Hasil statistic deskiptif untuk variabel gaya hidup $\left(\mathrm{X}_{1}\right)$, dapat dilihat bahwa distribusi data dari variabel Demografi mendekati pola kurva normal. Dengan demikian data variabel demografi dinyatakan terdistribusi normal. sehingga sebaran data variabel gaya hidup dapat dikatakan berdistribusi normal dan layak untuk menjadi alat ukur penelitian ini. Sedangkan untuk varibael demografi dapat dilihata dari gambar berikut:

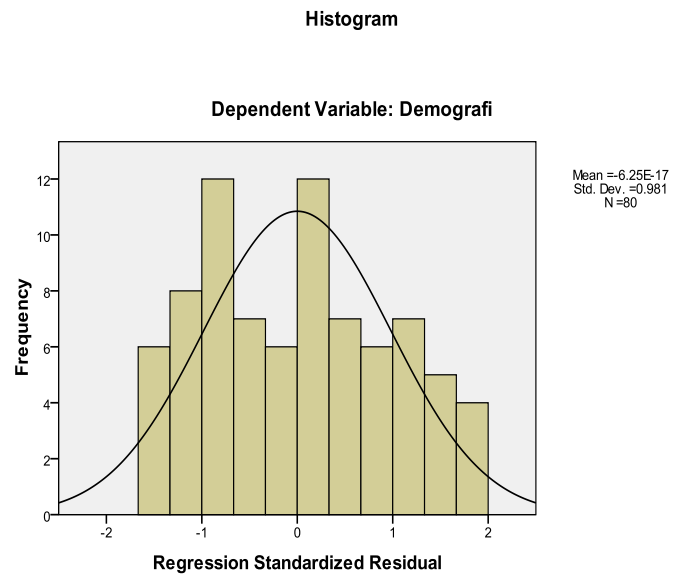

Gambar 5 Histogram Variabel Demografi Sumber : Data SPSS yang Diolah 2019

Hasil statistic deskiptif untuk variabel Demografi $\left(\mathrm{X}_{2}\right)$, dapat dilihat bahwa distribusi data dari variabel gaya hidup mendekati pola kurva normal. Dengan demikian data variabel gaya hidup dinyatakan terdistribusi normal. sehingga sebaran data variabel Demografi dapat dinyatakan berdistribusi normal.selanjutnya untuk variabel kualitas Produk (X3) dapat dilihat pada gambar berikut:

\section{Histogram}

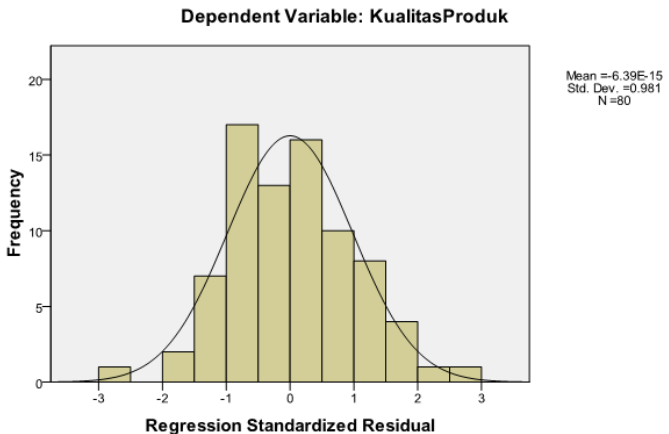

Gambar 6 Histogram Variabel Kualitas Produk (X3) Sumber : Data SPSS yang Diolah 2019

Hasil statistic deskiptif untuk variabel Kualitas Produk $\left(\mathrm{X}_{3}\right)$, dapat dilihat bahwa distribusi data dari variabel Kualitas Produk mendekati pola kurva normal. Dengan demikian data variabel Kualitas Produk dinyatakan terdistribusi normal.

Histogram

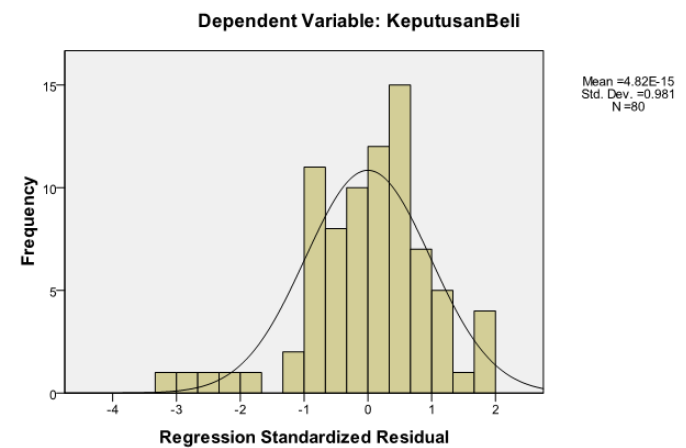

Gamber 7 Histogram Variabel Keputusan Pembelian Sumber: Data SPSS yang Diolah 2019

Hasil statistik deskiptif untuk variabel Keputusan Pembelian (Y), dapat dilihat bahwa distribusi data dari variabel Keputusan Pembelian mendekati pola kurva normal. Dengan demikian data variabel Keputusan Pembelian dinyatakan terdistribusi normal.

\section{Uji Homogenitas}

Uji homogenitas varian bertujuan untuk menentukan apakah varian kedua kelompok homogen atau tidak (D. Sugiyono, 2008). Uji homogenitas digunakan untuk mengetahui apakah beberapa varian populasi data adalah sama atau tidak. Homogenitas dilakukan untuk mengetahui apakah data dari masing-masing kelompok mempunyai varian yang sama atau berbeda sehingga dapat ditentukan rumus t-test mana yang akan dipilih untuk pengujian hipotesis 
atau dengan kata lain nilai signifikansinya melebihi 0,05 (Priyatno, 2010). Pengujian homogenitas varian menggunakan uji homogeneity pada tabel reliability statistics dengan bantuan program SPSS.20 for windows dan dapat disajikan dalam bentuk gambar Scatterplot seperti gambar berikut:

Scatterplot

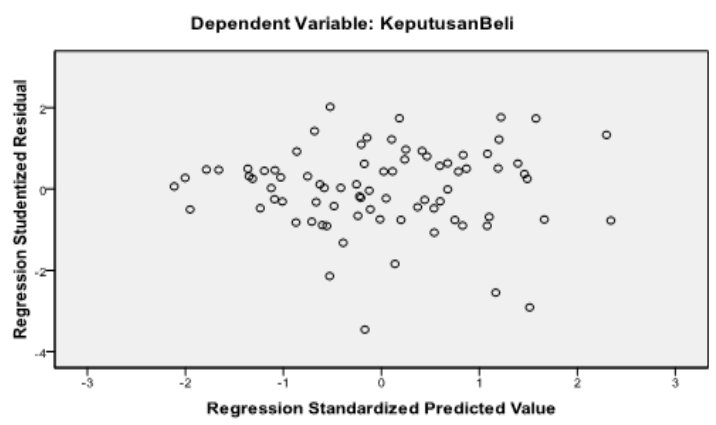

Gambar 8 Homogenitas Scatterplot

Sumber: Data SPSS yang Diolah 2019

Dapat dilihat dari gambar 8 terlihat bahwa titik-titik menyebar secara acak tidak membentuk pola tertentu yang jelas, seperti bergelombang, melebar kemudian menyempit. Selain itu titik-titik tersebut menyebar diatas dan dibawah angka pada sumbu Y, maka dapat disimpulkan bahwa data adalah homogen.

\section{Pengujian Hipotesis}

\section{a. Uji Regresi Linier Berganda}

Perhitungan regresi linier berganda digunakan untuk memprediksi besarnya hubungan antara variabel terikat (dependen) yaitu Keputusan Pembelian (Y), dengan variabel bebas (independen) yaitu Gaya Hidup $\left(\mathrm{X}_{1}\right)$, Demografi $\left(\mathrm{X}_{2}\right)$, dan Kualitas Produk $\left(\mathrm{X}_{3}\right)$. Analisis Regresi Linier Berganda (Multiple Linear Regression Analysis) merupakan pengembangan dan analisis regresi sederhana dimana terdapat lebih dari satu variabel independen $x$. Secara umum model regresi linier berganda:

$$
Y=a+b_{1} X_{1}+b_{2} X_{2}++b_{3} X_{3}+\ldots . e
$$

\section{Keterangan:}

$\mathrm{Y}=$ Keputusan Pembelian

a = Bilangan Konstan

$\mathrm{b}=$ Koefisien Regresi

$\mathrm{X}_{1}=$ Skor variabel Gaya Hidup

$\mathrm{X}_{2}=$ Skor variabel Demografi

$\mathrm{X}_{3}=$ Skor variabel Kualitas Produk

e $=$ Pengaruh variabel - variabel lain.
Perhitungan penelitian dengan aplikasi komputer SPSS dengan modul regresi linier berganda dapat dilihat dibawah ini

Tabel 2 Hasil Uji Regresi Berganda Coefficients $^{\mathrm{a}}$

\begin{tabular}{|c|c|c|c|c|c|}
\hline & \multirow[t]{2}{*}{ Model } & \multicolumn{2}{|c|}{$\begin{array}{l}\text { Unstandardize } \\
\text { d Coefficients }\end{array}$} & \multirow[t]{2}{*}{$\mathrm{t}$} & \multirow[t]{2}{*}{ Sig. } \\
\hline & & $\mathrm{B}$ & $\begin{array}{l}\text { Std. } \\
\text { Error }\end{array}$ & & \\
\hline 1 & (Constant) & $\begin{array}{r}2,32 \\
6\end{array}$ &, 327 &,- 998 & ,320 \\
\hline & $\begin{array}{l}\text { Gaya } \\
\text { Hidup }\end{array}$ & ,296 & ,064 & 4,589 & ,000 \\
\hline & Demografi & ,221 & ,099 & 2,244 & 027 \\
\hline & $\begin{array}{l}\text { Kualitas } \\
\text { Produk }\end{array}$ & ,431 & ,096 & 4,511 &, 000 \\
\hline
\end{tabular}

a. Dependent Variabel: Keputusan Pembelian

Sumber : Data SPSS yang Diolah 2019

Berdasarkan tabel 2 diketahui bahwa nilai konstanta a yang diperoleh sebesar -0,326, koefisien arah regresi $b_{1}$ sebesar 0,296, koefisien arah regresi $b_{2}$ sebesar 0,221, koefisien arah regresi b3 sebesar 0,431 . Persamaan penelitian sebagai berikut:

$Y=2,326+0,296 X_{1}+0,221 X_{2}+0,431 X_{3}+\ldots . e$

\section{b. Pengujian hipotesis t (uji t)}

Pengujian hipotesis ini untuk mengetahui apakah variabel independen berpengaruh secara terpisah atau parsial terhadap variabel terikat dan variabel independen (bebas) manakah yang paling dominan pengaruhnya terhadap Keputusan Pembelian. Kesimpulan yang dapat diambil berdasarkan pengujian hipotesis diatas adalah variabel gaya hidup, Demografi dan Kualitas Produk berpengaruh secara parsial terhadap Keputusan Pembelian. Dan yang mempunyai pengaruh paling dominan adalah Kualitas Produk.

Tabel 3 uji hipotesis $\mathbf{t}$ ( Uji t) Coefficients $^{\mathrm{a}}$

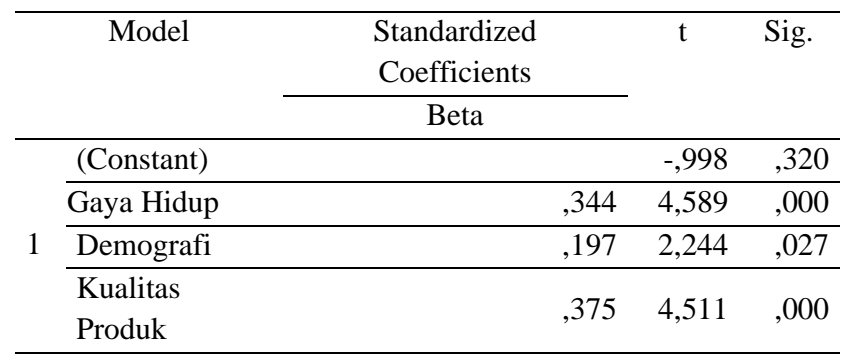

Dependent Variable: Keputusan Pembelian

Sumber : Data SPSS yang Diolah 2019 


\section{c. Pengujian Hipotesis F (Uji F)}

Pengujian hipotesis ini yaitu untuk mengetahui pengaruh antara seluruh variabel independen (bebas) dengan variabel dependen (terikat). Dalam hipotesis penelitian ini, diduga bahwa seluruh variabel gaya hidup $\left(\mathrm{X}_{1}\right)$, demografi $\left(\mathrm{X}_{2}\right)$ dan variabel Kualitas Produk $\left(\mathrm{X}_{3}\right)$ secara simultan mempengaruhi Keputusan Pembelian. Hasil pengujian hipotesis $\mathrm{F}$ dapat dilihat pada tabel berikut ini :

Tabel 4 Hasil Uji F (Anova)

\begin{tabular}{|c|c|c|c|c|c|}
\hline & ANO & & & & \\
\hline Model & $\begin{array}{l}\text { Sum of } \\
\text { Squares }\end{array}$ & df & $\begin{array}{c}\text { Mean } \\
\text { Square }\end{array}$ & $\mathrm{F}$ & Sig. \\
\hline $\begin{array}{l}\text { Regress } \\
\text { ion }\end{array}$ & 13,681 & 3 & 4,560 & 46,765 &, $000^{b}$ \\
\hline Residual & 10,337 & 106 & ,098 & & \\
\hline Total & 24,018 & 109 & & & \\
\hline a. Depender & t Variable: & Eeput & san Pemb & lian & \\
\hline $\begin{array}{l}\text { b. Predictor } \\
\text { Gaya hidup }\end{array}$ & : (Constan & $\mathrm{Ku}$ & itas Prod & $\mathrm{k}$, Den & grafi, \\
\hline
\end{tabular}

Berdasarkan hasil perhitungan yang dapat dilihat pada tabel 4.7, menunjukkan Signifikansi $F=0.000$. Jadi Sig F $<5 \%(0.000<0.05)$, dengan demikian Ha diterima dan Ho ditolak yang berarti bahwa secara serempak variabel $\mathrm{X}_{1}, \mathrm{X}_{2}, \mathrm{X}_{3}$ mempunyai pengaruh yang signifikan terhadap variabel $\mathrm{Y}$. Jadi terbukti bahwa variabel Gaya Hidup, Demografi dan Kualitas Produk berpengaruh secara bersama-sama terhadap Keputusan Pembelian.

\section{b. Koefisien Determinasi $\left(\mathbf{R}^{2}\right)$}

Koefisien determinasi berganda $\left(\mathrm{R}^{2}\right)$ digunakan untuk mengetahui besarnya sumbangan atau kontribusi dari keseluruhan variabel bebas pengaruhnya terhadap variabel terikat (Y), sedangkan sisanya dipengaruhi oleh variabel lain yang tidak dimasukkan dalam model. Hasil koefisien determinasi dapat dilihat pada tabel berikut :

Hasil Koefisien Determinasi (Model Summary Model Summary ${ }^{\mathrm{b}}$

\begin{tabular}{ccccc}
\hline $\begin{array}{c}\text { Mode } \\
1\end{array}$ & $\mathrm{R}$ & $\begin{array}{c}\mathrm{R} \\
\text { Square }\end{array}$ & $\begin{array}{c}\text { Adjusted R } \\
\text { Square }\end{array}$ & $\begin{array}{c}\text { Std. Error of the } \\
\text { Estimate }\end{array}$ \\
\hline 1 &, $755^{\mathrm{a}}$ &, 570 &, 657 &, 31228 \\
\hline
\end{tabular}

a. Predictors: (Constant), Kualitas Produk, Gaya Hidup,Demografi

b. Dependent Variable: Keputusan Pembelian

Sumber : Data SPSS yang Diolah 2019

Berdasarkan Tabel diatas dapat diketahui bahwa koefisien determinasi (Adjusted $\mathrm{R}^{2}$ ) sebesar 0,657 atau $65,7 \%$. Artinya variabel $\mathrm{Y}$ dijelaskan sebesar $65,7 \%$ oleh variabel Gaya Hidup $\left(X_{1}\right)$, Demografi $\left(\mathrm{X}_{2}\right)$ dan variabel Kualitas Produk $\left(\mathrm{X}_{3}\right)$ sedangkan sisanya sebesar $34,3 \%$ dijelaskan oleh variabel lain yang tidak diteliti dalam penelitian ini.

\section{KESIMPULAN}

Berdasarkan hasil analisis dan pembahasan mengenai pengaruh Gaya Hidup, Demografi dan Kualitas Produk terhadap Keputusan pembelian pada Gerai Alfamart Sukaseuri Cikampek, maka dapat ditarik kesimpulan sebagai berikut:

a. Variabel Gaya Hidup mempunyai pengaruh positif terhadap Keputusan Pembelian karena dari hasil uji hipotesis $t$ nilai signifikansinya $0,000<$ sig. 0,05 .

b. Variabel Demografi mempunyai pengaruh positif terhadap Keputusan Pembelian. karena dari hasil uji hipotesis t nilai signifikansinya 0,027 < sig. 0,05 .

c. Variabel Kualitas Produk mempunyai pengaruh positif terhadap Keputusan Pembelian karena dari hasil uji hipotesis $t$ nilai signifikansinya $0,000<\operatorname{sig} .0,05$

d. Variabel Gaya Hidup, Demografi dan Kualitas Produk berpengaruh secara simultan atau bersama-sama dan signifikan terhadap Keputusan Pembelian karena dari hasil uji hipotesis F nilai signifikansinya $0,000<$ sig. 0,05 .

\section{REFERENSI}

Ardy, D. A. P. (2013). Pengaruh Gaya Hidup, Fitur, Dan Harga Terhadap Keputusan Pembelian Blackberry Curve 9300. Jurnal Ilmu Manajemen, 1(1), 223-233.

BPS Karawang. (2019). Jumlah Penduduk Menurut Kelompok Umur dan Jenis Kelamin di Kabupaten Karawang. Retrieved from https://karawangkab.bps.go.id/

Dewi, N. M. (2015). Resistensi Pedagang Terhadap Implementasi Kebijakan Relokasi Pasar Waru Sidoarjo. Jurnal Politik Muda, 4(1), 126-136.

Ediyanto, M. N. M., \& Satyahadewi, N. (2013). Pengklasifikasian Karakteristik Dengan Metode K-Means Cluster Analysis. Bimaster, 2(02).

Fuad, A. (2015). Pengaruh gaya hidup terhadap keputusan pembelian konsumen di purworejo. Segmen-Manajemen, 11(2A).

Ghanimata, F., \& Kamal, M. (2012). Analisis pengaruh harga, kualitas produk, dan lokasi terhadap keputusan pembelian (Studi pada Pembeli Produk Bandeng Juwana Elrina Semarang). Fakultas Ekonomika dan Bisnis.

Ghozali, I. (2011). Aplikasi Analisis Multivariate Dengan Program IBM SPSS 19 (edisi kelima. Semarang: UNIVERSITAS NEGERI SEMARANG.

Harmadi, S. H. B. (2008). Pengantar Demografi. Lembaga Demografi Fakultas Ekonomi Universitas Indonesia. Jakarta.

Herawati, T. (2014). Pengaruh Sistem Pengendalian Intern Terhadap Kualitas Laporan Keuangan 
(Survei Pada Organisasi Perangkat Daerah Pemda Cianjur). STAR-Study \& Accounting Research, 11(1), 1-14.

katadata.co.id. (n.d.). Berapa Jumlah Gerai Grup Alfamart? Retrieved from Berapa Jumlah Gerai Grup Alfamart?\%0A\%0AArtikel ini telah tayang di Katadata.co.id dengan judul [\%22Berapa Jumlah Gerai Grup Alfamart?\%22] https://databoks.katadata.co.id/datapublish/201 7/11/20/berapa-jumlah-gerai-grup-alfamart

Kodu, S., \& Produk, K. (2012). Harga, kualitas produk dan kualitas pelayanan pengaruhnya terhadap keputusan pembelian mobil toyota avanza. 1(3), 1251-1259.

Permana, M. V. (2013). Peningkatan Kepuasan Pelanggan melalui Kualitas Produk dan Kualitas Layanan. Jurnal Dinamika Manajemen, 4(2).

Priyatno, D. (2010). Teknik mudah dan cepat melakukan analisis data penelitian dengan SPSS dan tanya jawab ujian pendadaran. Yogyakarta: Gava Media.

Sugiyono, D. (2008). Metode penelitian bisnis. Bandung: Pusat Bahasa Depdiknas.

Sugiyono, H. (2016). Metode kualitatif dan kuantitatif. Cetakan Ke-23. Alfabeta, Bandung.

\section{PROFILE PENULIS}

Suhardi, Karawang sebagai kota tempat tinggal, gelar S.Sos diraih pada tahun 2010 di fakultas Dakwah dan Komunikasi dengan konsentrasi Jurnalistik UIN Sunan Gunung Djati Bandung dan gelar MM diraih pada tahun 2015 dari Universitas BSI Bandung. Serta saat ini aktif sebagai Dosen tetap di UBSI Jakarta. 